\title{
MILLİ MÜCADELE DÖNEMINDE MUHITTIN BAHA PARS
}

\author{
Yrd. Doç Dr. Celil BOZKURT ${ }^{*}$
}

\begin{abstract}
$\ddot{O} z$
Muhittin Baha Pars, yakın dönemde Bursa'nın sosyal ve siyasal yașamında etkili olmuş aydinlardan biridir. Milli Mücadele'de Bursa'da oluşturulan milli direnişin mimarlarından olan Muhittin Baha Bey, Bursa Redd-i İlhak ve Bursa Müdafaa-i Hukuk Cemiyetlerinin kurucuları arasında yer almıştır. Muhittin Baha Bey'in yayımladığ Millet Yolu ve Bursa Mecmuası, Bursa halkının işgallere karşı bilinçlenmesinde ve Kuvay-i Milliye'ye desteğine önemli katkllar sunmuştur. Muhittin Baha Bey, Bursa milletvekili olarak Birinci TBMM'ye girmiş ve Milli Mücadele'yi yürüten meclisin en aktif vekillerinden olmuştur. Mecliste Mustafa Kemal Paşa yanlısı tutumuyla dikkat çeken Muhittin Baha Bey, 1. Grup'ta yer almıs ve grubun aldığ kritik kararlarda söz sahibi olmuştur. Başkomutanlık ve İstiklal Mahkemeleri gibi önemli kanunların çıkarılmasında ciddi hizmetleri olmuştur. Milli Mücadele'de ortaya koyduğu vatansever tutumu ve fedakar çalışmalarıyla dikkat çeken Muhittin Baha Bey, büyük zaferin kazanılmasında pay sahibi olmuştur.
\end{abstract}

Anahtar Kelimeler: Muhittin Baha Pars, Bursa, Milli Mücadele, İstiklal Mahkemeleri, Millet Yolu, Bursa Mecmuast.

\begin{abstract}
Muhittin Baha Pars is one of the intellectuals recently been influential in social and political life of Bursa. Muhittin Baha Bey who was one of the architects of the national resistance created in Bursa during National Struggle, also was among the founders of the "Bursa Refusal of Annex" and "Bursa Defense Law Society". Muhittin Baha Bey were offered a significant contribution in the awareness of the people against the occupation and to support the Nationalists by publishing the Road of Nation and the Journal of Bursa. Muhittin Baha Bey, entered Parliament as the first deputy of Bursa and became one of the most active deputies of the Parliament which executing the national strugle. Muhittin Baha bey known as supporter of Mustafa Kamal, has taken place in 1st Group and was closely involved
\end{abstract}

* Düzce Üniversitesi Uluslararası İlişkiler Bölümü. 
with critical decisions. He has been serious role in issuing ordinances such as "Act of Supreme Millitary Commander" and "Act of Independence Courts". Noted for its patriotic attitude and altruistic work revealed in the National Struggle Baha Pars $B e y$, has a role in victory of great war.

Keywords: Muhittin Baha Pars, Bursa, National Struggle, Independence Courts, Nation Road, Bursa Journal.

\section{Giriş}

Muhittin Baha Bey, Bursa'nın ve Türkiye Cumhuriyeti'nin yakın dönem tarihine tanıklık etmiş önemli bir şahsiyettir. Özellikle de Milli Mücadele'nin sürdürüldügü dönemde Birinci TBMM'nin önde gelen milletvekillerinden olmuş, Mecliste yapılan müzakere ve alınan kararlarda etkili olmuştur. Hakkında yazılanların bölük pörçük bilgilerden öteye gitmediği Muhittin Baha Bey'in, akademik bir araştırmaya konu edilmesi zaruridir. Muhittin Baha Bey'in Milli Mücadele dönemi faaliyetlerine geçmeden önce onun hayat hikayesini özetlemek, ileride yapılacak değerlendirmelerin daha sağlıklı yapılması açısından önem arz etmektedir.

Muhittin Baha Pars, 1884 yılında Bursa'da doğdu. Babas1, Baba Efendi Tekkesi Şeyhi Bahaattin Efendi, annesi Nakiye Hanım'dır. Baba soyu, II. Murat döneminde Pars Bey olarak yaşamış Şeyh Abdullah oğlu Bedrüddin Mahmut Beye dayanır. Muhittin Baha Bey'in büyük ağabeyi Mehmet Baha Bey ünlü bir bestekâr olup, Abdülhak Hamit Tarhan'ın manzum piyesi Nesteren'i ve onun eşi Fatma Hanım'ın ölümü üzerine yazdığı Makber şirini besteledi. Ayrıca Türkiye'nin ilk müzik dergilerinden olan Alem-i Musiki'yi yayımladı. Geleneksel Türk musikisi alanında yarattığ 1 pek çok parçaların yanında marşlar ve operetler de besteleyen Mehmet Baha Bey'in çok sayıda şark1, müzikli temsiller ve güfteleri ile birlikte kendisine ait olan çocuk şarkıları da bulunmaktadır. Muhittin Baha Bey'in küçük ağabeyi Hakkı Baha Bey, Bursa'da İdadi-i Askerisinde, İstanbul'da Harbiye ve Erkan-1 Harp Mektebi'nde okudu. 1906'da yüzbaşı rütbesinde iken, Selanik'te, sonradan "İttihat ve Terakki Fırkası"na dönüşecek olan "Osmanlı Hürriyet Cemiyeti"nin on kurucusu arasinda yedinci sirada yer aldı. 1907'de Cemiyet'in adı "İttihat ve Terakki Cemiyeti" olarak değiştirildi. Bu dönemde, Harbiye'den sınıf arkadaşı Mustafa Kemal'i, Suriye'deki sürgün yaşamından firar ederek Selanik'e geldiği sırada Cemiyet'e üye yaptı. ${ }^{1}$

Muhittin Baha Bey, Bursa'da Erkek Lisesi'ni, ardından İstanbul Hukuk Fakültesi'ni bitirdi. 1909 yılında Bursa Bidayet Mahkemesi'ne atand1. 1920-

1 Yılmaz Akkılıç, Yakın Geçmişten Ü̧̧ Kardeşin Portresi Mehmet Baha, Hakkı Baha, Muhittin Baha, Bursa Defteri, Sayı 2, Haziran 1999, s.26-33. 
1921 ve 1922-1923 arasında iki defa Hudavendigar Vilayeti Davavekilleri Cemiyeti'nin (Bursa Barosu) başkanlığını yaptı. Mondros Ateşkes Antlaşmasi'ndan sonra Bursa'da kurulan ve tehcir edilen Ermenilerin davasını gören Bursa İdare-i Örfiye Mahkemesi'nde ücret almaksızın Bursalı memurların dava vekilliğini üstlendi. ${ }^{2}$ Eğitmenlik yönü de bulunan Muhittin Baha Bey, Bursa Sultanisi'nde uzun yıllar edebiyat, mantık ve felsefe öğretmenliği yaptı. ${ }^{3}$

Muhittin Baha Bey, yerel ve ulusal bir çok derneğin kuruculuğunu yaptı ve yöneticileri arasında bulundu. TBMM'de bulunduğu sıralarda 7 Mayıs 1921'de Ankara'da kurulan Milli Mücadele yanlısı Türkiye Muallime ve Muallimler Dernekleri Birlik'in kurucuları arasında yer aldı. Birlik'in 1922 yılında oluşturulan Geçici İdare Heyeti'nin başkanlığını üstlendi. ${ }^{4}$ 22-26 Nisan 1924 tarihinde Ankara'da toplanan Türk Ocakları Umumi Kongresi'nde Merkez Heyeti üyeleri arasında yer aldı. Ayrıca, 23 Nisan-1 Mayıs 1925 tarihleri arasında Ankara'da toplanan Türk Ocakları II. Kurultayı'nda Merkez Heyeti üyeliğine seçildi. ${ }^{5}$

23 Nisan 1920'de TBMM'nin açılmasıyla birlikte aktif siyasete atılan Muhittin Baha Bey, birinci TBMM'ye Bursa milletvekili olarak girdi. Ardından on iki yıl siyasetten uzak kaldı. Bu süre zarfinda Bursa'da avukatlık, eğitmenlik ve farklı derneklerde yöneticilik yaptı. 1935 'te yeniden siyasete dönen Muhittin Baha Bey, TBMM'nin Beşinci Yasama Döneminde (1935-1939) Ordu milletvekili seçildi. Ardından, TBMM'nin Altıncı (19391943), Yedinci (1943-1946) ve Sekizinci (1946-1950) Yasama dönemlerinde kesintisiz olarak Bursa milletvekilliği yaptt. ${ }^{6} 1950$ ve 1954 'te CHP'den yeniden Bursa milletvekili adayı olduysa da seçimi kazanamadı. Muhittin Baha Bey, 29 Ağustos 1954'te Bursa'da vefat etti. Mezarı, diğer ağabeyleri gibi Emir Sultan Mezarlı̆̆ı'ndadır.

\section{Bursa'daki Faaliyetleri}

Muhittin Baha Pars, Mondros Ateşkes Antlaşması'ndan sonra ülkeyi saran işgallere karşı Bursa halkına yön veren lider şahsiyetlerden biri oldu. $\mathrm{O}$, Mondros'un hemen ardından Bursa Mecmuasi'nda kaleme aldığ 1 "Felaket Karşısında" başlıklı uzun yazıda Bursalılara seslenmiş, halka sağ duyulu bir

2 http://www.bursabarosu.org.tr/sayfalar.php?sayfa=12

3 Başbakanlık Osmanlı Arşivleri (BOA), Dahiliye Nezareti Emniyet-i Umumiye Müdüriyeti Evrak Odas1 (DH.EUM.VRK), 25/49.

4 İsmail Göldaş, Milli Kurtuluş Savaşında Öğretmenler, Öğretmen Dünyası Yayınları, İstanbul 1981, s.44-45.

5 İbrahim Karaer, Türk Ocakları, Türk Yurdu Neşriyatı, Ankara 1992, s.184-185.

6 TBMM Albümü 1920-2010, (Editör: Sema Yıldırım, Behçet Kemal Zeynel), 1.Cilt, TBMM Basın ve Halkla İlişkiler Yayınları, Ankara 2010, s.458. 
kurtuluş reçetesi sunmuştu. "Düçar olduğumuz müthiş felaket-i mağlubiyet karşısında kayıp ettiğimiz şeylerin matem-i zıyaını tutarken, gözlerimizi kapamamalı, ayn felakete tekrar düçar olmaktan sıyanet-i nefs için istikbali düşünmeliyiz" diyen Muhittin Baha Bey, halkı uyanık olmaya ve gerekli dersi çıkarmaya çağırıyordu. Bunun yanında "kendimize bihakkın sahib, mevcudiyet-i milliyemizi bihakkın müdrik olmadıkça üstümüzden böyle kuvvetlerin eksilemeyeceği" gerçeğini hatırlatan Muhittin Baha Bey, daha o günlerde milli iradenin gücüne işaret ediyordu:

"Mağlubiyet ne kadar büyük olursa olsun, milletimizin azim ve imanı yanında küçük kalmalıdır. Düşmanlar orduları mağlub ve hatta imha etse de, yaşamak isteyen bir milleti ortadan kaldırmaya muvaffak olamaz. Mevcut bir millet ise bütün yaşayanlar gibi tekamüle namzettir. Şu halde bize düşen vazife mazinin kara günlerini atiye aksettirerek ümitlerimizi zaaf ve izmihlale düşünmekten ictinab ve tecrübelerden istifade ederek çalışmak, çalışmaktır. Hüsn-ü niyet ve vukuf ile icra edilen müşterek sai, bir millet için mutlaka hayırlı ve nafi' eserler vücuda getirir.."7

Muhittin Baha Bey, Milli Mücadele'de Bursa'da işgallere karşı ortaya çıkan ve halkın Milli Mücadele bilincini uyandırmayı hedefleyen tüm oluşumlarda görev aldı. Bursa'da sürdürdüğü milli faaliyetlerden dolayı dönemin Bursa Valisi Gümülcineli İsmail Hakk1 Bey tarafından Konya'ya sürgün olarak gönderildi. Sonradan 56. Tümen Komutanı Albay Bekir Sami Bey'in 27 Haziran 1919'da Bursa'ya gelmesi ve Vali İsmail Hakk1 Beyin İstanbul'a kaçmasından sonra Bursa'ya dönebildi. ${ }^{8}$

\subsection{Bursa Redd-i İlhak Cemiyeti}

Yunanlıların İtilaf Devletleri'nin desteğinde, 15 Mayıs 1919'da İzmir'i işgal etmesi tüm ülkede nefretle karşılandı. Mondros Mütarekesi ahkamına aykırı olarak işgallerin günden güne artması ve işgal sahalarına hakim olan vahşet ve katliam ameliyesi Türk insanını harekete geçirdi. Ülkenin bir çok bölgesinde işgallere karşı "Redd-i ilhak" ve Müdafaa-i Hukuk" namıla direniş örgütleri oluşturuldu. Başlangıçta, propaganda ve yayın yoluyla bulundukları bölgelerin haklarını koruyan bu örgütler, zamanla silahlı mücadeleyi benimsemeye başladi. ${ }^{9}$

Bursa'da Milli Mücadele Döneminde kurulan ilk savunma örgütü olan Bursa Redd-i İlhak Cemiyeti 1919 Temmuzu'nda kuruldu. Cemiyetin

7 Bursa Mecmuasl, 26 Muharrem 1337/ 1 Kasım 1918, Say1 21.

8 Akkılıç, a.g.m., s.31.

9 Bayram Sakallı, Milli Mücadele'nin Sosyal Tarihi, İz Yayıncılık, İstanbul 1997, s.140147. 
kurucuları arasında Muhittin Baha ve ağabeyi Hakk1 Baha Bey de bulunmaktayd $1 .{ }^{10} \mathrm{Bu}$ örgütün oluşumu, Yunan tehdidi karşısındaki diğer bölgelere göre daha geç ve oldukça yavaş biçimde gerçekleşti. $\mathrm{Bu}$ gecikmenin başlıca nedeni, Bursa'da Saray ve İtilafçıların kuvvetli etkinliğiydi. Cemiyet, türdeş bir fikir yapısından yoksun olup, farklı görüşte üyelerden oluşmaktaydı. Kimileri, olayların gelişimiyle Kuva-yı Milliye'ye ve özellikle de -hilafetçi yapıları dolayısıyla- Anadolu Hükümeti'nin dönüşüm sürecine karşı çıktı ve zaman içinde tasfiye edildi. Bazıları da Milli Mücadele'ye açıç̧a cephe alarak işgalcilerle işbirliğine girdi.

Bursa Redd-i İlhak Cemiyeti, faaliyetlerini İsmet İnönü Caddesi'nde bulunan Yağcı Cemal Bey'in dükkanının üstünde bulunan Avcılar Kulübü'nden yürütmekteydi. Cemiyet, daha sonra İzmir Oteli'nin karşısında bulunan Terzi Muhittin Bey'in dükkanının bulunduğu sokakta başka bir eve taşındı. Cemiyetin gönüllü veya profesyonel nitelikte silahlı elemanları bulunmaktayd $1 .{ }^{12}$ Cemiyet, bir kaç aylık bir faaliyet döneminden sonra Bursa Müdafaa-i Hukuk Cemiyeti'ne iltihak etti.

\subsection{Bursa Müdafaa-i Hukuk Cemiyeti}

İşgallere karşı ülke genelinde faaliyette bulunan Müdafaa-i Hukuk örgütleri, Sivas Kongresi'nde Anadolu ve Rumeli Müdafaa-i Hukuk Cemiyeti altında bir araya getirildi. Ayrıca, her vilayette bu cemiyete bağlı olarak müdafaa-i hukuk şubeleri kurulmaya başlandı. Sivas Kongresi'nden yaklaşık bir ay sonra Bursa Müdafaa-i Hukuk Cemiyeti kuruldu. Cemiyetin merkezi, daha önce Bursa Redd-i İlhak Cemiyeti'ne idari merkezlik yapan Setbaşı'ndaki Avcılar Kulübü'ydü. Cemiyetin merkezi, sonradan Yeniyol'daki İstanbul Oteli karşısında bulunan Edremit Oteli'ne taşındı. ${ }^{13}$

\footnotetext{
${ }^{10}$ Cemiyetin diğer kurucuları şunlardır: Erzurumlu Salih Hoca, İdare Meclisi Başkatibi Hami, Hasan Sami, Yenişehirli Hafız Abdullah, Paşa Çiftliği Sahibi Ali, Ali Ruhi, Memduh, İstinaf Mahkemesi Başkanı Hasan (Süleyman Vehbi), Müftü Hafız Ahmet, Gürcü Murtaza, Murat, Müderris Kara Yusuf, Nasuh Zade Saim, Urgancı Abdullah, Fesçi Hafiz Halit, Su Müdürü Salih, Öğretmen Okulu Müdürü Hamid, Şer'iye Mahkemesi Başkatibi Nurettin, Dr. Mehmet Ali, Eczacı Şükrü, Defterdarlıktan emekli Raif, oğlu Celal, Dr. Şefik Hidayet, Emekli Kurmay Binbaşı Nevres, Öğretmen Hüsnü Uluğ, Değirmenci Ömer Ağa, Cemil, Jandarma Alay Komutanı Albay İsmail Hakkı, Dişçi Anber, Operatör Emin, lise öğretmenlerinden Ali Rıza, Tabak Tevfik Ağa, Soğanlı Çiftliği Sahibi Ethem, Hacı İvas Çiftliği Sahibi Mustafa, Tabak Eşref, Tüccar Hüseyin Avni ve Binbaşı Mehmet Ali Beyler. Bkz. Mümtaz Şükrü Eğilmez, Milli Mücadele'de Bursa, İstanbul Tarih Yayınları, İstanbul 1980, s.189.

${ }^{11}$ Yılmaz Akkılıç, Kurtuluş Savaşı'nda Bursa, Birinci Kitap, Mondros'tan İşgale, Nilüfer Akkılıç Kütüphanesi Yayınları, Bursa 2008, s.70-72.

${ }^{12}$ Akk1lıç, a.g.e., s.56.

${ }^{13}$ Eğilmez, a.g.e., s.189-190.
} 
Temsil Heyeti Başkanı Mustafa Kemal Paşa, 11 Ekim 1919'da Sivas'tan Bekir Sami Bey'e gönderdiği şifreli telgrafta, Bursa'da güvenilir kişilerden oluşan bir heyet-i merkeziye kurulmasını ve Bursa dahilinde nahiyelere varıncaya kadar bir Müdafaa-i Hukuk örgütlenmesine gidilmesini istedi. $\mathrm{Bu}$ doğrultuda Bursa Müdafaa-i Hukuk Cemiyeti'nin merkez heyeti oluşturuldu $^{14}$ ve heyet, 10 Ekim 1919 tarihinden itibaren çalışmalara başladı. Cemiyetin ilk başkanlığına Bursa Redd-i İlhak Cemiyeti'nin önde gelenlerinden Erzurumlu Salih Hoca (Mehmet Salih Yeşil) getirildi. Cemiyetin merkez heyetinde bulunan Muhittin Baha Bey, Bursa Müdafaa-i Hukuk Cemiyeti'nin aldığı kritik kararlarda doğrudan etkili oldu. Cemiyetin ilk bildirisi, onun görüşleri dahilinde hazırlandı. Cemiyetin 1920 Nisanında yapılan genel toplantısında başkanlığa Muhittin Baha Beyin ağabeyi Hakkı Baha Bey seçildi. ${ }^{15}$

Bursa Müdafaa-i Hukuk Cemiyeti, propaganda organı olarak 22 Şubat 1336 (1920) tarihinde basin hayatına giren Millet Yolu gazetesini kullanmaktaydı. Gazetenin sahibi ve mesul müdürü Muhittin Baha Bey'di. Bursa'da Vilayet Matbaası'nda basılan gazetenin masrafları, Müdafaa-i Hukuk Merkez Heyeti tarafindan karşılanmaktaydı. ${ }^{16}$ Gazete başlığının altında "Hukuk ve Hakimiyet-i Milliye'nin Müdafi-i Yevmi Gazetedir" ibaresi yer alırken, logonun altında da Tevfik Fikret'in:

"Millet yoludur, hak yoludur tuttuğumuz yol

Ey hak yaşa, ey sevgili millet yaşa, varol"

misraları bulunmaktaydı. ${ }^{17}$ Millet Yolu, cumartesi günleri hariç her gün yayımlanmaktaydı. Gazete, 1927 yılına kadar faaliyette kaldı.

Millet Yolu, Milli Mücadele ruhunu uyandırmakla birlikte, o günlerde Türk insanına örnek bir devrim olarak gösterilen Rusya'daki Bolşevik hareketin ateşli savunuculuğunu da yapmaktaydı. Gazete, İngiliz istihbarat raporlarına girecek kadar solcu bir kimlik taşımaktaydı. 15 ve 22 Temmuz 1920 tarihli İngiliz istihbarat raporlarına göre gazetede, Bolşevizm'in neleri savunduğu, neleri gerektirdiği ve temel ilkelerinin neler olduğuna dair diziler yayımlaniyordu. ${ }^{18}$

\footnotetext{
${ }^{14}$ Cemiyet, şu kişilerden oluşmaktaydı: Başkan Erzurumlu Salih Hoca, Muhittin Baha, Nasuh Zade Sadık, Urgancı Abdullah, Bursa Kadısı Tahir, Avukat Osman Nuri, Emekli Yüzbaşı Hacı Ahmet, Binbaşı Abdullah, Müderris Kara Yusuf, Ahmet Muhtar, Mümtaz Şükrü ve Gemlikli Necati beyler. Bkz. Eğilmez, a.g.e., s.189.

${ }^{15}$ Saime Yüceer, Bursa'nın İşgal ve Kurtuluş Süreci, Uludağ Üniversitesi Basımevi, Bursa 2001, s.48-51.

${ }^{16}$ Yücel Öztürk, Bursa Basın Tarihi, Ekin Yayınevi, Bursa 2012, s.164.

${ }^{17}$ Millet Yolu, 7 Şaban 1338/26 Nisan 1920.

${ }^{18}$ Mete Tunçay, Türkiye'de Sol Akımlar (1908-1925), 3. Basım, Bilgi Yayınevi, Ankara 1978, s.192.
} 


\section{Türkiye Büyük Millet Meclisi'ndeki Faaliyetleri}

Bu bölümde Muhittin Baha Beyin Milli Mücadele döneminde TBMM çatısı altında yürüttüğü faaliyetler ele alınmıştır. Öncelikle, TBMM'deki konumu ve görev aldığı komisyonlar özetlenmiş, ardından Yeşil Ordu, Türkiye Komünist Partisi, İstiklal Mahkemeleri ve Türkiye Muallim ve Muallimeler Birliği'ndeki dikkat çekici faaliyetleri değerlendirilmiştir..

Mustafa Kemal Paşa, İstanbul'un 16 Mart 1920'de resmen işgal edilmesinin ardından Temsil Heyeti adına bütün illere, bağımsız sancaklara ve kolordu komutanlıklarına bir genelge gönderdi. Genelgede Osmanlı Mebusan Meclisi'ne katılan üyelerin yanı sıra sancaklarda seçimler yapılmasını ve yeni üyelerin 15 gün içinde Ankara'ya gönderilmesini istedi. Bursa Sancağı'nda yapılan seçimlerde Muhittin Baha (Pars), Operatör Emin (Erkul), Necati (Kurtuluş) Beyler ile Mustafa Fehmi (Gerçeker) ve Şeyh Servet (Akdağ) Efendiler milletvekili seçildi. Söz konusu isimler, daha önce Osmanlı Mebusan Meclisi'nde Bursa'yı temsil eden Osman Nuri (Özpay) ve Hasan Fehmi (Kokay) Beylerle birlikte TBMM'ye katıld1. ${ }^{19}$

Bursa milletvekilleri, TBMM'ye katılmak üzere 6 Nisan 19120 tarihinde Ankara'ya hareket etti. Hareketten bir gün sonra Millet Yolu gazetesinde Muhittin Baha Beyin Bursalı hemşerilerine hitaben yazdığı bir veda yazısına yer verildi. Muhittin Baha Bey, Türk insanının "hukuk-u aliye-i hilafetin, haysiyet ve istiklal-i milletin muhafazası uğrunda" kararlı olduğunu belirtiyor ve TBMM'nin görevini "yık1lmak istenilen taht-1 saltanat1 terhin ve sir edilmek istenilen milleti layık olduğu mertebe-i bülende isal" olarak niteliyordu. ${ }^{20}$

Muhittin Baha Bey, TBMM'nin açıldığı andan itibaren değişik komisyonlarda sorumluluk aldı ve çalışmalarıyla Meclisin dikkat çeken vekillerinden biri oldu. İlk olarak TBMM'nin 23 Nisan 1920 tarihli Birinci Oturumunda Mustafa Kemal Paşa'nın tavsiyesiyle Meclis Başkanlık Kurulu katipliğine seçildi. ${ }^{21}$ Sonradan olışturulan Maarif Encümeni başkanlığına getirildi. ${ }^{22}$ Ayrica, 27 Nisan 1920'de Bursa milletvekili Şeyh Servet Efendi'nin takririyle kurulan ve Milli davanın propagandasını yapan İrşad Encümeni'ne dahil oldu. ${ }^{23}$

Muhittin Baha Bey, 10 Mayıs 1920'de TBMM'de kurulan Anadolu ve Rumeli Müdafaa-i Hukuk Grubu'nun yönetim kurulunu oluşturan on iki

${ }^{19}$ TBMM Albümü, s.18-19.

20 "Sevgili Hemşehrilerime", Millet Yolu, 18 Recep 1338/7 Nisan 1920.

${ }^{21}$ Türkiye Büyük Millet Meclisi (TBMM), Zabit Ceridesi (ZC), Devre 1, Cilt 1, Oturum 1, 23 Nisan 1336 (1920), s.2.

22 TBMM Albümü, s. 19.

${ }^{23}$ TBMM ZC, Devre 1, Cilt 1, Oturum 15, 13 Mayıs 1336 (1920), s.280. 
üyeden biriydi. ${ }^{24}$ Bundan dolayı, Grubun Mecliste aldığ 1 kritik kararlarda daima ön planda yer aldı. 5 Ağustos 1921'de TBMM'de cereyan eden Başkumandanlık Kanunu müzakerelerinde kanunun ateşli savunucularından biri oldu. Bu hususta 2. Grubun liderlerinden Hüseyin Avni Beyle girdiği tartışma dikkat çekicidir. Mustafa Kemal Paşa'ya üç ay süreyle Meclisin fiili yetkilerini veren beş maddelik kanun önergesini veren dokuz kişilik listede Muhittin Baha Beyin de imzası vardı. ${ }^{25}$ Şairlik yönü de bulunan Muhittin Baha Bey, 1921'de Maarif Vekaleti tarafından açılan istiklal marşı yarışmasına katıldı. Yarışmaya 724 şiir iştirak etti ve en beğenilen altı şiir Meclis Matbaası'nda basılarak milletvekillerine dağıtıldı. Muhittin Baha Beyin, "M" rumuzuyla yazdığı üç kıtalık şiir bunlar arasındaydı. Fakat, yarışmanın galibine vaat edilen 500 liralık ödül Meclis'te tartışma konusu olunca Muhittin Baha Bey şiirini yarışmadan geri çekti. ${ }^{26}$ Yarışmayı, Burdur Milletvekili Mehmet Akif Beyin yarışma dışından yazdığı "Kahraman Ordumuza" adlı 10 kıtalık şiiri kazandı.

Muhittin Baha Bey, 28 Haziran 1923'te yapılan milletvekili genel seçimlerinde aday gösterilmedi. Bursa milletvekili 2. Kolordu Komutanı General Ali Hikmet Ayerdem'in milletvekilliğinden istifa etmesiyle boşalan yer için 1925 te yapılan ara seçimlerde Bursa'dan bağımsız aday oldu. Fakat, rakibi Nurettin Paşa'ya karşı seçimi kaybetti. ${ }^{27}$ Muhittin Baha Bey, 1935'te Ordu milletvekili seçilinceye kadar uzun bir süre siyasetten uzak kaldı.

\subsection{Yeşil Ordu Cemiyeti}

Yeşil Ordu'nun kimliğinin tespitinde ve gerçekte ne amaçla kurulduğuna dair farklı fikirler öne sürülmüştür. Yeşil Ordu adı ilk kez Rusya'da bir efsane halinde duyuldu. Yeşil Ordu, Kafkas Türkleri ve Müslümanları tarafından kurulan ve Bolşevik Kızılordu ile birlikte İngiliz yanlıs1 hükümetlere karş1 çarpışan bir ordunun adıydı. Anadolu gazetelerinde, sınırımızı aşarak Erzurum'a doğru gelmekte olan böyle hayali bir Yeşil Ordu'nun müjdesi verilmekteydi. TBMM Hükümeti, Rusya'dan Anadolu'ya gelecek yardım kuvvetlerine verilen Yeşilordu adının ülke içinde efsaneleşen tesirlerini ortadan kaldırmak istiyordu. Bundan dolayı Mustafa Kemal Paşa, TBMM içinde beliren Bolşeviklik tehlikesini önlemek, onu kontrol altına almak ve kendilerinden yardım umulan Bolşevikleri gücendirmeden oyalamak için bir yerli Yeşil Ordu teşkilatının resmen

${ }^{24}$ Ahmet Demirel, Birinci Mecliste Muhalefet, İletişim Yayınları, 2. baskı, İstanbul 1995, s. 220

${ }^{25}$ TBMM Gizli Celse Zabıtları (GCZ), Cilt 2, 5 Ağustos 1337 (1921), s.164-185.

${ }^{26}$ TBMM ZC, Devre 1, Cilt 9, Oturum 6, 12 Mart 1337 (1921), s.85.

27 "Nurettin Paşa Muhittin Baha'ya karşı kazalarda ekseriyet aldı", Cumhuriyet, 3 Şubat 1925. 
kurulmasını istedi. Ayrıca, bazı milletvekili olan yakın arkadaşlarını kendi istek ve teklifleri ile bu kuruluşun Genel Merkez Heyeti'nde görevlendirdi. ${ }^{28}$

Yeşil Ordu Cemiyeti, 1920 Mayısı'nda ortaya çıtı. Cemiyet, resmi bir beyanname ile ortaya çıkmayan gizli bir örgüttü. Fakat, Mustafa Kemal'in bilgisi dahilinde kuruldu. Cemiyetin Genel Merkez Kurulu'nda TBMM'den aralarında Muhittin Baha Bey'in de bulunduğu on üç milletvekili yer ald. ${ }^{29}$ Daha sonra Çapanoğlu Ayaklanması'nı bastırdığı sırada Ankara'ya gelen Çerkes Ethem de cemiyete katıldı. Böylelikle, cemiyetin ciddi bir silahlı gücü de oluşmuş oldu. Çerkes Ethem, 1920 Ağustosunda Eskişehir'de Arif Oruç'la birlikte Seyyare Yeni Dünya adlı günlük bir "İslam Bolşevik" gazetesi çıkarmaya başladı. Gazetenin adı ve başındaki "Dünyanın Fukara-i Kasibesi Birleşiniz" sözü (Yeşil Ordu kavramı gibi) Sovyet Müslümanlarından esinlenmiş görünmektedir. ${ }^{30}$

Yeşil Ordu, kimliğini "Avrupa emperyalizminin hulül ve istila siyasetini Asya'dan tard etmek üzere teşekkül etmiş bir mücadele kuruluşu" olarak açıklamaktaydı. Cemiyet, "Yeni Dünya" olarak nitelediği Rusya'daki Bolşevik devrimini Anadolu insanına hedef göstermekte; kurtuluşu, bir İslam-Bolşevizm ittihadında mümkün görmekteydi. ${ }^{31}$

Yeşil Ordu'nun kuruluş ve gelişme devrelerinde Bursa'nın özel bir yeri bulunmaktadır. Cemiyetin on üç yöneticisinden beşi Bursa ile doğrudan veya dolaylı olarak ilişkili kişilerdi. Bunlar, Şeyh Servet Efendi (Nakşibendi şeyhi, 1. Dönem Bursa mebusu), Muhittin Baha Bey (1. dönem Bursa mebusu), Çerkes Reşit Bey (Ethem Bey'in ağabeyi, o zamanlar Hüdavendigar Vilayetinin sınırları içinde bulunan Bandırma'nın Karacabeye daha yakın Emreköy'den), Hakkı Behiç Bey (1. Dönem Ertuğrul (Bilecik) mebusu, Anadolu ve Rumeli Müdafaa-i Hukuk Cemiyeti Temsil Kurulu'nda Bursa temsilcisi ve Gemlik doğumlu Mahmut Celal Bey (Bayar, 1. Dönem Saruhan mebusu) idi. ${ }^{32}$ Bunların içinde Muhittin Baha Bey'in Yeşil Ordu'nun Bursa örgütlenmesinde ayrı bir yeri vardır. Akkılıç, Yeşil Ordu'nun Bursa'da bir önceki evresi olarak tanımladığı Teali İslam Cemiyeti ile Muhittin Baha

${ }^{28}$ Fethi Tevetoğlu, Milli Mücadele Yıllarındaki Kuruluşlar, Türk Tarih Kurumu Basımevi, Ankara 1998, s.198.

${ }^{29}$ Yeşil Ordu Cemiyeti'nin Genel Merkez Kurulu'nda yer alan milletvekilleri şunlardı: Şeyh Servet (Akdağ), Dr. Adnan (Adıvar), Hakkı Behiç (Bayiç), Eyüp Sabri (Akgöl), Yunus Nadi (Abalığlu), Hüsrev Sami (Kızıldoğan), İbrahim Süreyya (Yiğit), Reşit, Sırrı (Bellioğlu), Mustafa (Cantekin), Hamdi Namık (Gör), Muhittin Baha (Pars), Nazım (Öztelli). Bkz: Tunçay, a.g.e., s.136-137; Tevetoğlu, a.g.e., s.220.

${ }^{30}$ Tunçay, a.g.e., s.144-145.

${ }^{31}$ Yeşil Ordu'nun yayımladığı beyanname, talimatname ve nizamname için bkz. Tevetoğlu, a.g.e., s.225-230.

32 Akkıliç, a.g.e., s.182-183. 
Bey arasında doğrudan bir ilişki olduğu kanaatindedir. 19 Şubat 1919'da İstanbul'da kurulan Teali İslam Cemiyeti'nin 18 şubesi arasında Bursa ve Yenişehir de bulunmaktaydı. Muhittin Baha Bey'in yönetiminde çıkan Bursa Mecmuası'nda Cemiyetin bildirileri yayımlanmaktaydı. Cemiyetin, 1920 başlarında yayımladığı bir bildiride Bolşevizm'le özdeşleştirdiği Kuva-yı Milliyeyi sert şekilde eleştirmesi üzerine Anadolu'da bulunan birçok şubesi cemiyetle bağlarını kesmişti. Akkılıç'a göre, Teali-i İslam Cemiyeti'nin tasfiye olmasından sonra milliyetçiliğe sempati duyan eski üyeler Yeşil Ordu'da bir araya gelmişti. ${ }^{33}$ Bursa Ziraat Okulu Müdürü Refet Bey de anılarında Muhittin Baha Bey'in Yeşil Ordu'nun Bursa'daki örgütlenmesinde önemli bir rolünün olduğunu belirtmektedir. Refet Bey'in yazdığına göre, İstanbul Hükümeti'nin teşvikiyle Bursa'da ayaklanmalar çıkarmak kastıyla bazı gizli kuruluşlar kurulmuştu. Bunun üzerine Ankara'da milletvekili bulunan Muhittin Baha Bey, Bursa'ya gelerek Yeşil Ordu adında Bolşevik bir örgütün derhal kurulması gerektiğini ögütlemişti. Ardından, Refet Bey ve Çerkes Ethem'n kardeşi Reşit Bey, Albay Bekir Sami Bey'in liderliğinde bir araya gelerek Yeşil Ordu'yu kurmuştu. ${ }^{34}$

Yeşil Ordu, zamanla amacından sapması ve başına buyruk hareket etmesi üzerine 1920'nin sonlarında tasfiye edildi. Mustafa Kemal Paşa, Sovyetlerle ilişkilerin bozulmaması için yerine resmi Türkiye Komünist Partisi'ni kurdurdu. Bazı Yeşil Ordu üyeleri bu partiye ilhak ederken, kapatılma kararına tepki gösteren kimi üyeler de "Halk-1 İştirakıyyun Fırkası"nı kurarak Ankara Hükümeti'nin denetimi dışına çıktılar.

\subsection{Türkiye Komünist Partisi}

Türkiye Komünist Partisi (TKP), 18 Ekim 1920'de resmen kuruldu. Partinin önde gelen diğer üyeleri arasında Tevfik Rüştü (Aras), Mahmut Esat (Bozkurt), Yunus Nadi (Abalıŏlu), Kılıç Ali, İhsan (Eryavuz), Refik (Koraltan), Eyüp Sabri (Akgöl) ve Süreyya (Yiğit) bulunmaktaydı. ${ }^{35}$ Yeşil Ordu'nun önde gelen üyelerinden Muhittin Baha ve Hakkı Behiç Beyler, Mustafa Kemal Paşa'nın isteğiyle bu partiye geçti. Muhittin Baha Bey, TKP'nin genel sekreterlik görevini üstlendi.

TKP, üç aylık ömründe dikkat çeken bir faaliyette bulunmadı. Yayın organı olarak kullandığ1 Hakimiyet-i Milliye ve Yeni Gün gazetelerinden anlaşıldığına göre, komünizmin bazı doktrinel uygulamalarına taraftar olsa da Rusya'daki gibi kanlı bir devrimden yana değildi. TKP, Bat1 emperyalizmine karşıydı fakat ulusların özgürlüğüne ve kendi şartlarına göre uyarlanmış bir komünizme taraftard..$^{36}$

\footnotetext{
${ }^{33}$ Akk1lıç, a.g.e., s.181.

${ }^{34}$ Eğilmez, a.g.e., s.202.

${ }^{35}$ Tunçay, a.g.e., s.163.

${ }^{36}$ Tunçay, a.g.e., s.167-168.
} 
Muhittin Baha Beyin TBMM'deki TKP tartışmalarında ortaya koyduğu fikirler Komünizme bakışını göstermesi açısından net veriler sunmaktadır. TBMM'nin 22 Kasım 1920 tarihli oturumunda, Mustafa Kemal Paşa'nın Rusya'daki ihtilalı fenni ve ilmi tarzda incelemek üzere seçilen heyete İstiklal Mahkemesi üyesi Tevfik Rüştü Beyin de katılması yönünde tezkeresi Meclis'te bir komünizm tartışması doğurmuştur. Bir Rus muhaciri olan Siverek milletvekili Mustafa Lütfi Bey, TKP adına Rusya'ya gidecek heyetin Meclis adına gitmesini eleştirmiş ve TBMM'nin komünist fikirde olmadığını, ayrıca TKP üyelerinin, başlarındaki kalpağı kırmızı bir şeritle çevirmekle komünist olamayacağını ileri sürmüştür. Buna karşı söz alan Muhittin Bey, oldukça sert bir tonlamayla Mustafa Lütfi Bey'i eleştirmiş, TKP üyelerinin vatansever ve başlarındaki kalpakların da samimi bir gayeye yönelik olduğunu vurgulamıştır. Komünizmi "...memleketi kurtaracak, milleti kurtaracak, insaniyeti kurtaracak esasat-1 ilmiye" diye tanımlayan Muhittin Baha Bey, heyete seçilen üyelerin TKP'ye mensup olmakla ilmi ve ahlak1 seciyelerinden bir şey yitirmediklerini savunmuştur. ${ }^{37}$

Muhittin Baha Beyin benzer bir refleksini, TBMM'nin Rusya ve Ermenistan'la kurulan ilişkileri tartıştığı bir oturumda da görmekteyiz. Söz konusu oturumda Mustafa Kemal Paşa, Vekiller Heyeti adına söz almış ve Türk ordusunun mağlup ettiği Ermenistan'ın elindeki silahların alınmasıyla ilgili uzun bir izahat vermiştir. Daha sonra söz alan muhaliflerden Erzurum milletvekili Hüseyin Avni Bey, Ermenilerin güvenilmeyecek unsurlar olduğundan bahisle komünizm hakkında "...bir din, bir akide olarak memleketimize komünizm girmeyecektir. Bir çapulcu, bir yağmac1, bir cani sıfatıyla memleketimize girecektir" ifadelerini kullanmıştır. Tekrar söz alan Mustafa Kemal Paşa, TKP'de bulunan üyelerin gayet namuslu ve vatansever kişiler olduklarını vurgulayarak, komünizmden gelebilecek zararlara karşı gerekli tedbirlerin alınacağını ifade etmiştir. Buna cevap veren Hüseyin Avni Bey, Rusların yakınlaştıkları milletlere komünizmi enjekte etmek niyetinde olduklarını, TBMM'nin Ruslarla sadece emperyalizme karşı ortak olduğunu, milli amaç ve duygu yönünden ayrı olduğunu ileri sürmüştür. Yeniden söz alan Mustafa Kemal Paşa, Ruslarla olan ortaklığın sadece kapitalizm aleyhinde olduğunu, Ruslara verilmiş herhangi bir sözün olmadığını ve Komünizmin Türk milleti için bir "sosyal sorun" olduğunu beyan etmiştir. Tartı̧̧maların şiddetlenmesi üzerine söz alan Muhittin Baha Bey'in Hüseyin Avni Beye yönelik olarak sarf ettiği şu ifadeler dikkat çekicidir:

"Efendiler pek çok söyleyecek değilim. Yalnız Hüseyin Avni Beyin bir millete bihakkın vaki olan buğuz ve kin tesiriyle bir

${ }^{37}$ TBMM ZC, Devre 1, Cilt 6, Oturum 101, 22 Kasim 1336 (1920), s.16. 
mesleki içtimaiye vaki olan taarruzu protesto etmek için çıktım. Burada bir Komünist Partisi vardır ve onun azası, bir Komünist Partisi teşkil etmekle, en büyük bir vazife-i içtimaiye ve bir vazife-i vataniye ifa ettiklerinden emindir. Arkadaşlarımız anlamak icap eder ki, Komünist Partisine iştirak edenler, hudud-u milliye hürmetkar ve onun için hayatların feda etmeye her an amadedirler. Komünist Partisine iştirak eden emindir ki, bu davalarında, bu partiyi teşkil etmekte ve bu davada ilerlemekte en büyük vatanperverliklerini zzhar etmişlerdir ve ediyorlar ve edeceklerdir. Komünist Partisi hudud-u milliyenin, Misak-ı Milli dahilinde mevcudiyetini kabul eder ve onun için hayatını fedaya ahdeder. Biz böyle kabul etmişizdir. Bolşevikler de milletlerin arzularina müracaat ederek hükümetlerinin teşsekküllünü kabul ettirmiştir. ${ }^{38}$

\section{3 İstiklal Mahkemeleri}

TBMM'nin 23 Nisan 1920'de Ankara'da resmen aç1larak faaliyete geçmesi, Milli Mücadele'nin seyrinde bir dönüm noktası oldu. Meclisle birlikte millete mal edilen Milli Mücadele, daha örgütlü ve topyekun bir zeminde gerçekleşmeye başladı. Fakat, TBMM'nin açılmasıyla birlikte yurdun farklı bölgelerinde Meclise karşı isyanlar patlak verdi. TBMM, otoritesini korumak için 29 Nisan 1920'de çıkarılan "Hıyanet-i Vataniye Kanunu" çıkardı. Fakat, bu kanun beklenen asayiş ve huzur ortamını yaratamadı. Bu hususta, cepheye yakın bölgelerde faaliyet gösterecek ve hızlı karar verip uygulayacak mahkemelere ihtiyaç duyuldu. Buna yönelik olarak TBMM'nin 11 Eylül 1920 tarihli oturumunda dokuz maddelik "Firariler Hakkında Kanun" kabul edilerek "İstiklal Mahkemeleri" kuruldu. ${ }^{39}$ Genel Kurmay Başkanı İsmet Bey'in teklifi ile Ankara, Eskişehir, Konya, Isparta, Sivas, Kastamonu ve Pozantı'da olmak üzere yedi mahalde İstiklal Mahkemesi kuruldu. Sonradan Diyarbakır'da da bir mahkemenin kurulması kararlaştırıldi ${ }^{40}$

TBMM'nin 21 Eylül 1920 tarihli oturumunda Muhittin Baha Bey, 73 oy alarak başkanlığını Antalya milletvekili Rasih Beyin yaptığ 1 Eskişehir İstiklal Mahkemesi'ne üye seçildi. Mahkemenin diğer üyeleri, Kütahya milletvekili Haydar Bey ve Denizli Milletvekili Yusuf Bey'di. ${ }^{41}$

${ }^{38}$ TBMM ZC. Devre 1, Cilt 7, Oturum 28, 3 Ocak 1337 (1921), s.161.

${ }^{39}$ TBMM ZC. Devre 1, Cilt 4, Oturum 63, 11 Eylül 1336 (1920), s.84-89.

${ }^{40}$ TBMM ZC. Devre 1, Cilt 4, Oturum 67, 18 Eylül 1336 (1920), s. 198.

${ }^{41}$ TBMM ZC. Devre 1, Cilt 4, Oturum 69, 21 Eylül 1336 (1920), s.238. 
Eskişehir İstiklal Mahkemesi, 20 Ekim 1920 ile 17 Şubat 1921 tarihleri arasında görev yaptı. Mahkemenin faaliyet sahası, Eskişehir, Bilecik, Kütahya, İzmit ve Bursa idi. Eskişehir, İstanbul'dan gelen bozguncu ve casusların çalışma bölgesiydi. Mahkemenin dava konularını bölgeye has asker kaçakları, Kuvay-i İnzibatiye'ye katılmak, bozgunculuk, casusluk ve soygun suçları oluşturuyordu. Mahkeme, faaliyet sürecinde 470 beraat, 57 idam, 594 tecil edilmiş idam, 20 giyaben idam, 272 kürek ve 11.270 muhtelif cezaya hükmetti. ${ }^{42}$

İstiklal Mahkemelerinin aldığı tedbirler sayesinde, asker kaçakları önemli ölçüde önlendi, on binlerce kaçak ve bakaya cepheye sevk edildi. Fakat, mahkemelerin aldığı sert tedbirler, verilen idam cezaları ve mahkeme üyelerinin sorumsuzluğu Meclis'te tartışma konusu oldu. I. İnönü Savaşı'nın kazanılması, İstiklal Mahkemelerinin varlığını zorunlu kılan nedenleri büyük ölçüde kaldırdı. Nihayet, Meclis Başkanlığı'nın verdiği 2 Şubat 1921 tarihli kararla I. Dönem İstiklal Mahkemeleri-Ankara İstiklal Mahkemesi hariçkapatild1. $^{43}$

İstiklal Mahkemeleri'nin çalışmalarına son vermesinden bir ay sonra asker arasında kaçak olayları ve bozguncu propaganda belirgin şekilde arttı. Ayrıca, Orta Anadolu'da soygun, ayaklanma, kaçak ve adi suçlar hızla çoğalmaya başladı. Bu suçlara bakan normal mahkemeler, dosyaların çokluğu yüzünden davaları sonuçlandırmakta zorluk çekmeye başladı. TBMM'nin aldığı cezai tedbirler de sorunlara kalıcı çözüm getiremedi. Diğer taraftan, Türk ordusunun Kütahya-Eskişehir muharebelerinde Yunanlılara yenilmesi ve Ankara'nın tehlike altına girmesi Meclis'te büyük moral çöküntüsü yarattı. Bu durum İstiklal Mahkemeleri'nin yeniden kurulmasına zemin hazırladı. $^{44}$

İcra Vekilleri Heyeti Başkanı Fevzi Paşa, 23 Temmuz 1921'de TBMM'de yaptığı askeri durum hakkındaki konuşmasında Türk ordusunun güvenliğinin sağlanması için Konya ve Kastamonu'da iki İstiklal Mahkemesi'nin kurulmasını istedi. Ardından Sinop milletvekili Hakkı Hami Bey, Samsun'da da bir mahkeme kurulmasını uygun olacağını belirtti. Meclis, Konya, Kastamonu ve Samsun'da İstiklal Mahkemesi kurulmasını kararlaştırdı. ${ }^{45}$ Mahkemeler için yeniden üye seçimine karar verildi. Antalya milletvekili Tahsin Bey ile Mardin milletvekili İbrahim Bey, meclisin 24

${ }^{42}$ Ergün Aybars, İstiklal Mahkemeleri (1920-1927), Cilt I-II, Dokuz Eylül Üniversitesi Yayınlar1, İzmir 1988, s.78.

${ }^{43}$ TBMM ZC. Devre 1, Cilt 8, Oturum 152, 12 Şubat 1337 (1921), s.269-271.

${ }^{44}$ Aybars, a.g.e., s.97-98.

${ }^{45}$ TBMM ZC, Devre 1, Cilt 11, Oturum 54, 23 Temmuz 1337 (1921), s.348-353. 
Temmuz 1921 tarihli oturumunda verdikleri ortak takrirde 12 kişilik üyelik için 20 kişilik bir liste sundu. Fakat karar alınamadı. ${ }^{46} 28$ Temmuz'da yapılan ilk tur oylamasında Canik Milletvekili Emin Bey, 176 oyun 89'unu alan ilk üye oldu. Fakat, çoğunluğu sağlayan başka bir üye çıkmadı. ${ }^{47}$ Nihayet, 30 Temmuz'da yapılan oturumda 180 kişilik adaydan, aralarında Muhittin Baha Bey'in de bulunduğu 12'si İstiklal Mahkemeleri üyeliğine seçildi. ${ }^{48}$

Başkumandan Mustafa Kemal Paşa'nın isteği üzerine 8 Eylül 1921'de Yozgat İstiklal Mahkemesi kuruldu. Ankara'da bulunan mahkemeyle birlikte toplamda 5 İstiklal Mahkemesi oluşturuldu. Muhittin Baha Bey, başkanlığını Hacim Muhittin Beyin yaptığ 1 Konya İstiklal Mahkemesi'ne üye seçildi. ${ }^{49}$

Konya İstiklal Mahkemesi, 11 Ağustos 1921 'de Konya'da çalışmalarına başladı. Mahkeme, 12 Ağustos'ta yayımladığı bir beyannameyle göreve başladığını, düşman istilası altında olan memleketin içinde bulunduğu zor şartları ve Milli Mücadele'nin önemini belirtti. Mahkeme ayrıca, iki maddelik bir açıklamayla düşmana yardım edenleri, Milli Mücadeleye muhalif olanları ve müşkülat çıkaranları en şiddetli şekilde ikaz etti. ${ }^{50}$

Muhittin Baha Bey, annesinin rahatsızlı̆̆ nedeniyle sonradan mahkeme üyeliğinden ayrılmak zorunda kaldı. Bunun üzerine Mahkeme başkanı Hacim Muhittin Bey, 14 Nisan 1922'de Muhittin Baha Beye yazdığ 1 mektupta "kendi annesinin ölümüne bile gidemediğini" belirterek derhal göreve gelmesini istedi. Sonuç alamayınca, 27 Nisan ve 28 Haziran'da olmak üzere iki kez M. Kemal Paşa'ya ardından da bir kez TBMM'ye Muhittin Baha Bey'in altmış beş gündür göreve gelmediğini bildirdi. $\mathrm{Bu}$ arada Muhittin Baha Bey, 9 Haziran 1922'de istifa etti. Kısa süre sonra İstiklal Mahkemeleri kaldırıldığı için yerine kimse gönderilmedi. ${ }^{51}$

Konya İstiklal Mahkemesi, bir y1l boyunca Konya, Karaman, Ereğli, Anamur, Silifke, Pozantı, Niğde, Akşehir, Burdur, Isparta, Antalya ve Denizli'de faaliyet gösterdi. 1 Ağustos 1922 tarih ve 249 No'lu kanun gereğince mahkemenin görevine son verildi. Mahkeme, 16 Ağustos 1921 ile 22 Temmuz 1922 tarihleri arasında 1407 davayı sonuçlandırdı. $\mathrm{Bu}$ kararlardan 166'sı idam, 1479 'u da tecil edilmiş idam kararıydı. ${ }^{52}$

TBMM'nin 31 Temmuz 1922 tarihli oturumunda 15 maddelik 249 nolu "İstiklal Mehakimi Kanunu" çıkarılarak İstiklal Mahkemelerinin görev ve

${ }^{46}$ TBMM ZC, Devre 1, Cilt 11, Oturum 55, 24 Temmuz 1337 (1921), s.357-358.

${ }^{47}$ TBMM ZC, Devre 1, Cilt 11, Oturum 56, 28 Temmuz 1337 (1921), s.363-364.

${ }^{48}$ TBMM ZC, Devre 1, Cilt 11, Oturum 57, 24 Temmuz 1337 (1921), s.366-367.

${ }^{49}$ Aybars, a.g.e., s.102.

${ }^{50}$ Aybars, a.g.e., s.108.

${ }^{51}$ Aybars, a.g.e., s.113.

523 No'lu Konya İstiklal Mahkemesi'nin özetlenmiş faaliyet listesi için bkz: Aybars, a.g.e., s.118. 
sorumlulukları yeniden düzenlendi. Kanun görüşmelerinde söz alan Muhittin Baha Bey, mevcut adli mahkemelerin adaleti tam olarak tesis edemediğini ve suçluların serbestçe dolaştıklarını vurguladı. Konya'daki deneyimlerinden örnek veren Muhittin Baha Bey, özellikle hırsızlık ve rüşvet gibi suçlarda hızlı karar alıp uygulayan İstiklal Mahkemelerinin devreye girmesi gerektiğini savundu. $\mathrm{Bu}$ doğrultuda, Kanunun İstiklal Mahkemelerinin vazifelerini düzenleyen 3. Maddesinin "K" ve "S" fikraları Muhittin Baha Bey'in teklifiyle düzenledi. Buna göre, hırsızlık yapan, rüşvet alan mülki ve askeri memurlar, bunlara ortak olan ve aracilık yapanlar ( $\mathrm{K}$ fikrasi); memuriyet nüfuzunu kullanarak halka zulüm ve işkence yapan mülki ve askeri memurların yargılanması (S fikrası) İstiklal Mahkemeleri'nin görev kapsamına alındı. ${ }^{53}$

"İstiklal Mehakimi Kanunu" ile İstiklal Mahkemeleri'nin yetkileri ciddi şekilde sınırlandırıldı. Buna mukabil, mahkemelerde görev alan savcıların yetkileri genişletildi ve savcilar, karar alma sürecinde belirleyici duruma geldi. İdam kararları, Meclisin onayına bırakıldı. Böylelikle, mahkemeler ilk dönemindeki "İhtilal mahkemeleri" niteliğini kaybetti. Nihayet, 1 Ağustos 1922 'de kabul edilen yeni kanunla İstiklal Mahkemelerine son verildi. ${ }^{54}$

Milli Mücadele esnasında "...isyan sahalarında hayatlarını tehlikeye koyan ve en ağır mesuliyetlerini üzerlerine alarak mühim kararlar veren İstiklal Mahkemeleri azalar1" TBMM'nin 22 Nisan 1925 tarihli oturumunda takdirle anıldı. Dönemin Muş milletvekili İlyas Sami Bey ve 20 arkadaşının verdiği teklifle kendilerine kırmızı-yeşil kurdeleli istiklal madalyası verildi. ${ }^{55}$

İstiklal Mahkemelerinin kararları daima sorgulanmış, zaman zaman TBMM'de sert tartışmalara neden olmuştur. Özellikle muhalif milletvekilleri, mahkemelerin anti demokratik yapısını eleştirmiş ve onları türlü şekillerde insan hakları ihlali yapmakla suçlamıştır. Nitekim, TBMM'nin Hiyanet-i Vataniye Cürümlü Eşhasın Affina Dair Kanun görüşmelerinde mahkemeler yeniden gündeme gelmiştir. Görüşmelerde Hüseyin Avni Bey, "İstiklal Mahkemesine giden arkadaşlarımız devletin kuvay-i maddiye ve manevivesini başka şekilde tefsir ettiler. O kanun o kadar elastiki idi ki, ne yapılsa haklıdır" diyerek mahkemelerin amacından saptırıldığını ileri sürmüş ve hükmettiği bazı cezaların affını istemiştir. Buna cevap veren Muhittin Baha Bey, İstiklal Mahkemelerini şöyle savunmuştur:

"...Dün verdiğim kararlardan bugün muazzep değilim. Dünkü verilen kararın memleketin menfaatine hadim olduğuna kaani

${ }^{53}$ TBMM ZC, Devre 1, Cilt 22, Oturum 82, 29 Temmuz 1336 (1922), s.58.

${ }^{54}$ Aybars, a.g.e., s. 130.

${ }^{55}$ TBMM ZC, Devre 2, Cilt 18, Oturum 109, 22 Nisan 1341 (1925), s.393-394. 
olduğum gibi bugün dahi eminim ve iddia ediyorum...Biz bu memlekete hlyanet edenleri astık. Biz bu memlekete karşı gelenleri astik. Biz bu davanin aleyhinde bulunanları astik. Biz sizin aleyhinizde bulunanları astik...Diyorum ki efendiler, biz bu memleketi kurtarmak için adam astık..."${ }^{\prime 56}$

\subsection{Bursa'nın İşgal Sürecindeki Faaliyetleri}

15 Mayıs 1919'da İzmir'in işgaliyle başlayan Yunan istilası, zamanla tüm Ege bölgesine yayıldı. İngiliz desteğinde ilerleyen düzenli Yunan birlikleri, 22 Haziran 1920 tarihinde altı tümenlik bir kuvvetle bir kaç cepheden Anadolu'yu işgale başladı. 30 Haziran'da Balıkesir, 2 Temmuz'da Mustafa Kemal Paşa ve Karacabey Yunan birlikleri tarafından işgal edildi. Ardından, 6 Temmuz'da Gemlik ve Mudanya, 7 Temmuz'da da Karacabey işgal edildi. Nihayet Yunanlılar, bir direnişle karşılaşmadan 8 Temmuz 1920'de Bursa'y1 ele geçirdi. Bursa'y1 müdafaa eden kuvvetlerden Yarbay Nazmi Bey komutasındaki 56. Tümen tamamen dağıldı. 20. Kolordu Komutanı Yarbay Bekir Sami Bey de İnegöl istikametinden Eskişehir'e çekildi. $^{57}$

Bursa, asırların getirdiği bir gelenekle hilafet ve saltanata güçlü hislerle bağlıydı. Bundan dolayı, İstanbul Hükümetinin Kuva-yı Milliye hakkında yaptığı olumsuz propagandalar Bursa'da derin tesirler bıraktı. Şehir, İstanbul'la milli kuvvetler arasında tam bir bölünmüşlük içindeydi. $\mathrm{Bu}$ durum şehrin kolayca işgal edilmesinin nedenlerinden birisi oldu.

Bursa'nın işgali, tüm ülkede büyük bir üzüntü ve panik havası yarattı. Anadolu'nun değişik yerlerinde işgali protesto eden gösteriler düzenlendi. İsgale duyulan infial, TBMM'de bir duygu seline ve öfke patlamasına neden oldu. Meclisin 8 Temmuz 1921 tarihli oturumunda Genel Kurmay Başkanı İsmet Paşa, Yunanlıların ilerleyişi ve cephelerin durumu hakkında genel bir bilgilendirme yaptı. Ardından M. Kemal Paşa, "...efendiler, bazı yerler işgal edilmiştir ve bunun üç misli daha işgal olunabilir. Fakat bu işgal hiç bir vakitte bizim imanımızı sarsmayacaktır" diyerek milletvekillerine moral aşıladi ${ }^{58} 10$ Temmuz 1920 'de yapılan oturumda Trabzon milletvekili Hamdi Bey ve 30 arkadaşı, Bursa'nın işgaline karşı duyulan üzüntünün bir simgesi olarak meclis kürsüsüne siyah bir örtü asılmasını teklif etti. Teklif kabul edildi ve meclis kürsüsüne işgalin sona ermesine kadar siyah bir örtü asıldı. Oturumda, gayet sert tartışmalar yaşandı. Bazı milletvekilleri, Bursa'yı işgal

${ }^{56}$ TBMM ZC. Devre 1, Cilt 26, Oturum 170, 8 Ocak 1339 (1923), s.220-235.

${ }^{57}$ Selahattin Tansel, Mondros'tan Mudanya'ya Kadar, Cilt 3, Milli Eğitim Bakanlığı Yayınları, İstanbul 1991, s.157-166.

${ }^{58}$ TBMM ZC, Devre 1, Cilt 2, Oturum 30, 8 Temmuz 1336 (1920), s.226. 
eden Yunan ordusunda Halife ordusundan da katılımların olduğunu ifade ederek, İstanbul'u ihanetle suçladı. Burdur milletvekili İsmail Subhi Bey, verdiği takrirde Halife ordusunun desteğinde Bursa'yı işgal eden Yunanlıların şehirde yaptıkları "tahrip, tahrik ve Müslüman Türk kızlarının ırzlarını hetk ve telvis"i, işledikleri mezalim ve fecayiin tüm yurt genelinde duyurulmasını ve Türk insanında "milli heyecan ve intikam hislerinin uyandırılmasını" istedi. Bursa milletvekillerinin bu oturumda söz almaması dikkat çekti. ${ }^{59}$

TBMM'nin 12 Temmuz 1920 tarihi oturumunda Bursa'nın işgali tartışmaları aynı sertlikle devam etti. Mecliste ortaya çıkan hava, işgalde sorumlu görülen yetkililerden hesap sorulması idi. Oturumda söz alan Bursa kökenli Saruhan milletvekili Mahmut Celal (Bayar) Bey, Bursalıları savunan ve sağduyu mesajları veren uzun bir konuşma yaptı. ${ }^{60}$ Daha sonra Vekiller Heyeti kararıyla 20. Kolordu Komutanı Bekir Sami Bey'in görevine son verildi. Bekir Sami Bey, önce Antalya ve Havalisi Komutanlığı'na ardından da Kuzey Kafkasya Askeri Murahhaslığı görevine getirildi. ${ }^{61}$

Mustafa Kemal Paşa, Bursa'nın işgalinin ardından Batı Cephesi'nde askeri tetkiklerde bulunmak üzere bir grup milletvekiliyle birlikte Bilecik, Kütahya ve İnegöl hattına gitti. Meclis tarafindan seçilen bu milletvekillerinin arasında Bursa milletvekili Muhittin Baha Bey de yer aldı. Milletvekilleri 10 günlük tetkik ziyaretinden sonra TBMM'de ayrıntılı olarak cephe izlenimlerini anlattı. Muhittin Baha Bey, Batı cephesindeki son durum ve Bilecik'te sürgün bulunan Bursalı hemşerilerine dair Meclise bilgi verdi. Bursalıların hazin öyküsüne dikkat çeken Muhittin Baha Bey, Bursa'nın işgali sırasında sorumsuzlukla hatta düşmanla işbirliği yapmakla suçlanan Bursa halkını savunmayı bir "vazife-i milliye "addettiğini belirtti. Ardından, Bursalıların "vazife-i vataniyesini ifa etmekten" çekinmediklerini, gerçek suçluların bu memleketin münevverleri ve zenginleri olduğunu vurgulayarak konuşmasını bitirdi. $^{62}$

Bursa, işgalin birinci yıl dönümünde TBMM'de cereyan müzakerelerde yeniden ele alındı. Bursa'da işlenen Yunan mezalimi hakkında açılan müzakerede ilk sözü Bursa milletvekili Muhittin Baha Bey aldı. Oldukça duygusal ve ağlamaklı bir ses tonuyla konuşan Muhittin Baha Bey, Yunan işgalini betimlerken şunları söylüyordu.

"Efendiler, bütün ömründe mağlubiyet ne olduğunu bilmeyen bir dakika için zillet-i mă̆lubiyetin ne olduğunu tanımamış

\footnotetext{
${ }^{59}$ TBMM ZC, Devre 1, Cilt 2, Oturum 31, 10 Temmuz 1336 (1920), s.236-249.

${ }^{60}$ TBMM ZC, Devre 1, Cilt 2, Oturum 32, 12 Temmuz 1336 (1920), s.279-286.

${ }^{61}$ Yüceer, a.g.e., s.88-90.

${ }^{62}$ TBMM ZC. Devre 1, Cilt 3, Oturum 45, 9 Ağustos 1336 (1920), s.158-159.
} 
olan, bir dakika için mukaddesat ve hukukundan en küçügünü çiğnetmemiş olan Sultan Osman'ın türbesini biz efendiler bir sene evvel düssman ayakları altında biraktık. Efendiler, 365 gün evvel Osmanl tarihinin en yüksek servetlerini, en yüksek hatıratını, en büyük adamlarını, Müslümanlı̆̆ın bir çok evliyasının türbelerini Yunanlıların ayakları altında görmek bedbahtlı̆̆ııa duçar olduk." ${ }^{63}$

Ardından, Bursa'dan gelen son haberleri değerlendiren Muhittin Baha Bey, Yunanlıların her an Bursa'yı yakılabileceği konusunda milletvekillerinin dikkatini çekti. Bu haber Meclis'te gergin ve ümitsiz bir hava oluşturdu. Muhittin Baha Bey, gelen haberlerinin doğruluğuna o kadar çok inanmıştı ki, Bursa'nın yakılmasını peşinen kabul ediyor; fakat şehrin tarihine, padişah ve evliya türbelerine dokunulmaması için adeta yalvarıyordu. Konuşmasında, Eskişehir'de sürgün bulunan Bursalı hemşerilerine de değinen Muhittin Baha Bey, Nevres Ali Nuri imzasıyla kendisine gönderilen ve TBMM'ye olan güveni konu edinen telgrafı okudu. Ardından, Edirne milletvekili Şeref Bey, bir takrir vererek Yunanlıların Bursa'y1 yakacakları hususunda Hariciye Vekili'nin Meclise bilgi vermesini istedi. Hariciye Vekili Yusuf Kemal (Tengirşenk) Bey'in Bursa'nın işgaline değinmeden genel duruma dair verdiği bilgiler milletvekillerini tatmin etmedi. Bunun üzerine Muhittin Baha Bey'in verdiği bir takrir üzerine Meclis'te genel bir görüşme yapıld $1{ }^{64}$

Türk ordusu, 26 Ağustos 1922'de başlattığı Büyük Taarruz ve akabinde yaptığ 30 Ağustos 1922 tarihli Başkomutanlık Muharebesi sonunda Yunan kuvvetlerinin büyük bir kısmını imha etti. M. Kemal Paşa'nın 1 Eylül'de verdiği "Ordular! İlk hedefiniz Akdenizdir ileri!" emriyle birlikte Türk ordusu İzmir'e girdi. 11 Eylül'de de Bursa düşman işgalinden kurtuldu. ${ }^{65}$ Bursa'nın kurtuluşu yurt genelinde coşkulu bir sevinç yarattı. Milli Müdafaa Vekili Kazım Bey, TBMM'de milletvekillerine Bursa'nın kurtulduğu müjdesini verdi. Ardından, İzmir ve Bursa'nın kurtuluşundan dolayı M. Kemal Paşa'ya bir takrirle Türk milletinin şükran ve teşekkürleri sunuldu. ${ }^{66}$

Bursa'nın kurtuluşunun ilanıyla birlikte Bursa milletvekilleri Muhittin Baha, Dr. Emin ve Şeyh Servet Beyler Bursa'ya geldiler. Milletvekilleri, TBMM'ye gönderdikleri bir telgrafta Yunanlıların şehre zarar vermeye firsat bulamadan kaçtıklarını arz ederek, halkın TBMM'ye şükranlarını ve milli hükümete saygılarını sundular. ${ }^{67} 15$ Eylül 1922 günü Bursa'da kurtuluş

${ }^{63}$ TBMM ZC, Devre 1, Cilt 11, Oturum 48, 9 Temmuz 1337 (1921), s.187-189.

${ }^{64}$ TBMM ZC, Devre 1, Cilt 11, Oturum 48, 9 Temmuz 1337 (1921), s.187-217.

${ }^{65}$ Yüceer, a.g.e., s. 123.

${ }^{66}$ TBMM ZC, Devre 1, Cilt 23, Oturum 100, 11 Eylül 1338 (1922), s.619-620.

${ }^{67}$ TBMM ZC, Devre 1, Cilt 2, Oturum 32, 12 Temmuz 1336 (1920), s.279-286. 
vesilesiyle büyük bir miting düzenlendi. Bursa halkı, M. Kemal Paşa'ya bir şükran borcu olarak TBMM'nin Bursa'ya teşrifini arzuladı. Bunun üzerine bahsi geçen Bursa milletvekilleri ile Belediye Başkanı Muhtar Bey, TBMM'ye kendilerini Bursa'ya davet eden bir telgraf gönderdi. ${ }^{68} \mathrm{TBMM}$, bu konuyu Meclisin 23 Eylül 1922 'de yaptı̆ğ gizli oturumda geniş bir şekilde ele aldı. Oturumda, 45 milletvekilin Meclisin Bursa'ya gitmesi yönünde verdiği takriri değerlendirildi. Milletvekillerinin ikiye bölündüğü bu görüşmelerde, Meclisin mesai yoğunluğu göz önüne alınarak takririn ertelenmesine karar verildi. ${ }^{69}$ İlerleyen süreçte Meclisin Bursa'ya gitmesi mümkün olmadı.

\subsection{Muallim ve Muallimeler Cemiyeti'ndeki Faaliyetleri}

Ankara'da TBMM'nin açılmasıyla birlikte Anadolu'da bir demokratikleşme dönemi de başladı. Bundan yararlanan değişik dernek ve sendikalar, hem mesleki çıkarlarını savunmak hem de Milli Mücadele'ye katk1 vermek için bir örgütlenmeye girdi. Bunlardan biri de 1920 Temmuz'unda Ankara'da kurulan Muallim ve Muallimeler Cemiyet'iydi.

Genel katipliğini Kazim Nami'nin (Duru) yaptığı cemiyet, kuruluşu dolayısıyla TBMM'ye gönderdiği bir davetiyede meclis üyelerini Hac1 Bayram Veli'de okutacağ 1 bir mevlid-i Şerife davet ediyordu. ${ }^{70}$ Davetiye, Mecliste gayet olumlu tesirler bıraktı ve derneğin desteklenmesi yönünde bir hava oluşturdu. Dönemin Milli Eğitim Bakanı Dr. Rıza Nur, Anadolu'da Milli Eğitim müdürlüklerine gönderdiği bir genelgede cemiyetin diğer il ve bölgelerde de kurulmasını istedi. Bunun üzerine Anadolu'nun bir çok yerinde cemiyetin şubeleri açıld. ${ }^{71}$

Cemiyet, Kazım Nami'nin liderliğinde 7 Mayıs 1921'de Türkiye Muallim ve Muallimeler Cemiyeti Birlik adını aldı. Birlik'in kurucularından biri de öğretmen kökenli milletvekili Muhittin Baha Bey'di. Birlik'in bir yıl sonra yapılan seçiminde Muhittin Baha Bey, Birlik'in muvakkat idare heyeti başkanlığına seçildi. Heyette, İzmir milletvekili Mahmut Esat (Bozkurt) ve Kütahya milletvekili Cevdet Beyler de bulunmaktayd1. ${ }^{72}$ Muvakkat İdare Heyeti, 26 Haziran 1922 tarihinde Hakimiyet-i Milliye gazetesinde Birlik'in dünya görüşü, hedefleri ve faaliyet usullerine dair bir bildiri yayımladı. "Kardaşlar" hitabıyla başlayan bildiride Anadolu'nun Mondros Mütarekesi sonrasında maruz kaldığı yıkıcı işgallere dikkat çekiliyor; Türk milletinin, bağımsızlık ve özgürlüğü için her türlü mücadeleyi göze alacağı vurgulanıyordu. $\mathrm{Bu}$ mücadelede, öğretmenlere başat görev biçen Birlik;

${ }^{68}$ TBMM ZC, Devre 1, Cilt 2, Oturum 105, 20 Eylül 1338 (1922), s. 107.

${ }^{69}$ TBMM GCZ, Devre 1, Cilt 3, 23 Eylül 1333 (1922), s.806-811

${ }^{70}$ TBMM ZC, Devre 1, Cilt 2, Oturum 38, 21 Temmuz 1336 (1920), s.372-373.

${ }^{71}$ Tunçay, a.g.e., s.241.

${ }^{72}$ Göldaş, a.g.e., s.44-45. 
tarihte Almanya, Rusya ve Bulgaristan gibi ülkelerdeki başarılı devrimci hareketlerin arkasında fikir ordusunu oluşturan öğretmenlerin olduğunu vurguluyordu. Birlik, öğretmenleri bir "devrim savaşı" olarak gördüğü Milli Mücadeleye katılmaya çağırıyordu. Ayrıca, Mustafa Kemal Paşa'nın 1922 yılında TBMM'nin yıldönümünde söylediği "Türkiye'nin efendisi ve sahibi köylüdür" sözünü "memleketin devrim saatini çaldı" yargısıyla tevil eden bildiri, Türkiye Devrimi'nin öğretmenlerle kazanılacağını vurguluyordu. ${ }^{73}$

Birlik'in devrim vurgulu bildirisinin üstelik Anadolu Hareketi'nin propaganda gazetesi olan Hakimiyet-i Milliye'de yayımlanması, TBMM'de sert tartışmalara neden oldu. Karahisarı Sahip (Afyon Karahisar) mebusu İsmail Şükrü Efendi, TBMM'ye sunduğu önergede, bildiri içeriğinin bilimsel olmaktan ziyade "siyasi" olduğunu vurgulayarak İslamiyet'ten hiç bahsetmeyen bildirinin Almanya ve Rusya örneklerinde verilen Bolşevik vurguların yanlış anlaşılmalara neden olduğunu ileri sürdü. İsmail Şükrü Efendi; Dahiliye, Maarif ve Şer'iye (Adalet) vekaletlerine cevaplamaları istemiyle üç de soru yöneltti. Bunlar; Birlik'in Dernekler Kanunu'na göre kurulup kurulmadığı; hükümetin, Bolşevik bir devrime taraftar olup olmadığ1 ve hükümetin, gerek TBMM'ye karşı oluşabilecek güvensizlik, gerek eğitimin gidişatını etkilemesi bakımından ve gerekse de İslam esasları noktasında bildiriye karşı takip ettiği politikanın ne olduğu idi. ${ }^{74}$

Önergeye cevap veren Dahiliye Vekili Mehmet Ata Bey, Birlik'in Dernekler Kanunu'na uygun olarak kurulduğunu, siyasi bir içerik taşımadığını ve yayımladığı bildirinin halk arasında bir yanlış anlama meydana getirmediğini belirtti. Fakat, Mehmet Ata Bey, derneğin yönetim kurulunda bulunan tek kadın üye olan Leman Hanım'ı kast ederek erkek ve kadın öğretmenlerin bir arada çalışmasının gerek Maarif ve gerekse Ankara Valiliği tarafından uygun görülmediğini ilave etti. ${ }^{75}$

\section{SONUÇ}

Muhittin Baha Pars, Milli Mücadele döneminde Bursa'nın siyasal ve sosyal yaşamında doğrudan etkili olmuş bir aydındır. Bursa'da kurulan Redd-i İlhak ve Müdafaa-i Hukuk Cemiyetlerinin kuruluşunda görev almış, bu örgütlerin bağımsızlık yanlısı faaliyetlerinde önemli roller üstlenmiştir Muhittin Baha Beyin yayımladığ Millet Yolu ve Bursa Mecmuası, halkın işgallere karşı bilinçlenmesinde ve Anadolu hareketine katılmasında büyük katk1 sağlamıştır. Muhittin Baha Bey, milletvekilliği döneminde Bursa halkının Ankara'daki gözü kulağı olmuştur. Bursa'nın işgali sırasında

${ }^{73}$ Hakimiyet-i Milliye, 26 Haziran 1922.

${ }^{74}$ TBMM. ZC, Devre 1, Cilt 22, Oturum 84, 14 Ağustos 1338 (1922), s.162-163.

${ }^{75}$ TBBM. ZC, Devre 1, Cilt 22, Oturum 84, 14 Ağustos 1338 (1922), s.163. 
ihmalkarlıkla suçlanan Bursa halkına en büyük destek Muhittin Baha Pars'tan gelmiştir.

Muhittin Baha Pars, Milli Mücadele döneminde Bursa milletvekili olarak Birinci TBMM'ye girmiş ve Meclis'in önemli komisyonlarında görev almıştır. Meclis'te kurulan Anadolu ve Rumeli Müdafaa Hukuk Grubu'nun önde gelen üyelerinden olan Muhittin Baha Bey, grubun aldığ kritik kararlarda söz sahibi olmuştur. Muhittin Baha Bey, savaş yıllarında $\mathrm{M}$. Kemal Paşa'nın yanında yer almış ve kararlarına şartsız destek vermiştir. M. Kemal Paşa'ya üç ay boyunca Meclisin yetkilerini veren kanun önergesinde onun da imzası vardır. Aynı zamanda hukukçu bir kimliği olan Muhittin Baha Bey, Mecliste tartışılan pek çok kanunun şekillenmesinde uzman görüşleriyle katkılar sağlamıştır. Bunun en tipik örneklerinden biri de İstiklal Mahkemeleri Kanunu'dur. Mecliste şiddetli tartışmalara neden olan İstiklal Mahkemeleri Kanunu'nun formatında ve İstiklal Mahkemeleri'nin kuruluşunda Muhittin Baha Beyin önemli hizmetleri olmuştur. Eskişehir ve Konya İstiklal Mahkemelerinde fiilen görev yapan Muhittin Baha Bey, muhaliflere karşı daima İstiklal Mahkemeleri'nin arkasında durmuştur.

Muhittin Baha Pars, İslamcı/Bolşevik nosyonu bariz olan Yeşil Ordu ile Bolşevizmi bayraklaştıran resmi TKP'nin kurucu kadrosundandı. Ayrıca, Rus Devrimi'ni örnek alan Türkiye Muallim ve Muallimeler Cemiyeti Birlik'in başkanlığını üstlenmişti. M. Kemal Paşa'nın Sovyetlerden beklediği yardımları almak için özel olarak kurdurduğu bu örgütler, Mecliste şiddetli komünizm tartışmalarına neden olmuştur. Muhittin Baha Bey, Mecliste cereyan eden tartışmalarda Komünizmin ateşli savunucularından olmuş ve sıkça muhalif milletvekilleriyle karşı karşıya gelmiştir. Muhittin Baha Beyin Komünizm hakkında ortaya koyduğu samimi ve sitayişkar görüşler, onun dönemin koşullarına özgü bir tür solcu kimliğinde olduğunu göstermektedir.

\section{KAYNAKÇA}

ARŞIV BELGELERI

Başbakanlık Osmanlı Arşivleri (BOA), Dahiliye Nezareti Emniyet-i Umumiye Müdüriyeti Evrak Odası (DH.EUM.VRK), 25/49.

\section{RESMI YAYINLAR}

TBMM Albümü 1920-2010, (Editör: Sema Yıldırım, Behçet Kemal Zeynel), 1.Cilt, TBMM Basın ve Halkla İlişkiler Yayınları, Ankara 2010.

Türkiye Büyük Millet Meclisi (TBMM) Zabıt Ceridesi (ZC).

Türkiye Büyük Millet Meclisi (TBMM) Gizli Celse Zabıtları (GCZ). 


\section{KITAPLAR}

Akkılıç, Yılmaz; Kurtuluş Savaşı'nda Bursa, Birinci Kitap, Mondros'tan İşgale, Nilüfer Akkılıç Kütüphanesi Yayınları, Bursa 2008.

Aybars, Ergün; İstiklal Mahkemeleri (1920-1927), Cilt I-II, Dokuz Eylül Üniversitesi Yayınları, İzmir 1988.

Demirel, Ahmet; Birinci Mecliste Muhalefet, İletişim Yayınları, 2. baskı, İstanbul 1995.

Eğilmez, Mümtaz Şükrü; Milli Mücadele'de Bursa, İstanbul Tarih Yayınları, İstanbul 1980, s.189.

Göldaş, İsmail; Milli Kurtuluş Savaşında Öğretmenler, Öğretmen Dünyası Yayınları, İstanbul 1981.

Karaer, İbrahim; Türk Ocakları, Türk Yurdu Neşriyatı, Ankara 1992.

Öztürk, Yücel; Bursa Basın Tarihi, Ekin Yayınevi, Bursa 2012.

Sakallı, Bayram; Milli Mücadele'nin Sosyal Tarihi, İz Yayınc1lık, İstanbul 1997.

Tansel, Selahattin; Mondros'tan Mudanya'ya Kadar, Cilt 3, Milli Eğitim Bakanlığı Yayınları, İstanbul 1991.

Tevetoğlu, Fethi; Milli Mücadele Yıllarındaki Kuruluşlar, Türk Tarih Kurumu Basımevi, Ankara 1998.

Tunçay, Mete; Türkiye'de Sol Akımlar (1908-1925), 3. Basım, Bilgi Yayınevi, Ankara 1978.

Yüceer, Saime; Bursa'nın İşgal ve Kurtuluş Süreci, Uludağ Üniversitesi Basımevi, Bursa 2001.

\section{MAKALELER}

Akkılıç, Yılmaz; Yakın Geçmişten Üç Kardeşin Portresi Mehmet Baha, Hakkı Baha, Muhittin Baha, Bursa Defteri, Sayı 2, Haziran 1999.

"Nurettin Paşa Muhittin Baha'ya karşı kazalarda ekseriyet aldı", Cumhuriyet, 3 Şubat 1925.

\section{GAZETELER}

Bursa Mecmuast

Cumhuriyet

Hakimiyet-i Milliye.

Millet Yolu

\section{INTERNET KAYNAKLARI}

http://www.bursabarosu.org.tr/sayfalar.php?sayfa=12 